\title{
An abbreviated version of En-metena 1 from the Sulaymaniyah Museum
}

\author{
Ardalan Khwshnaw*, Gábor Zólyomi ${ }^{\ddagger}$ \\ * - Salahaddin University, Erbil. Email: khwshnaw.ardalan@gmail.com \\ $\ddagger-$ Department of Assyriology and Hebrew Studies, Eötvös L. University, Budapest. Email: zolyomi.gabor@ \\ btk.elte.hu
}

\begin{abstract}
This paper contains the publication of a previously unknown manuscript of En-metena 1 (RIME 1.9.5.1), which is kept in the Sulaymaniyah Museum in Iraq. The new manuscript contains an abbreviated version of the text compared to the text on the Louvre cone and the Yale jar. Although only about the half of the round object that carries the text is preserved, it may be estimated that the Sulaymaniyah manuscript originally was at least 89 lines shorter than the Louvre and the Yale manuscripts.
\end{abstract}

Keywords: Sumerian, En-metena, Lagaš, royal inscriptions, 3rd millennium BC

Cite as Khwshnaw, A., Zólyomi, G. 2020: An abbreviated version of En-metena 1 from the Sulaymaniyah Museum. Hungarian Assyriological Review 1, 21-37.

https://doi.org/10.52093/hara-202001-00002-000

(c)(i) $($ This is an open access article distributed under the terms of the Creative Commons Attribution License, which permits unrestricted use, distribution, and reproduction in any medium, provided the original author and source are credited.

\section{Introduction}

This joint paper is the publication of a previously unknown manuscript of En-metena 1 (RIME 1.9.5.1) (CDLI Q001103) ${ }^{1}$, which is kept in the Sulaymaniyah Museum in Iraq, its catalogue number is T.3860. ${ }^{2}$ The manuscript is registered on the website of CDLI with the P-number P481719. The text is unprovenanced, it was acquired by the Museum on 22 December 2010. T.3860 is a spherical, wheel made, jar-like clay object. The fragmentary object measures $11,8 \times 13,2 \mathrm{~cm}$ at its base. Only about the half of the round object that carries the text is preserved; consequently, its preserved 64 lines may represent only about less than half of its original lines. It has four columns.

En-metena 1 has had five manuscripts known until now: AO 3004 (CDLI P222532), NBC 2501 (CDLI P222533), AO 4443 (CDLI P222534), VAT 16438 (CDLI P418029), and UA-4743 (= IM 191931) (CDLI

1 For editions of En-metena 1, see Steible and Behrens 1982, I, 230-245; II, 112-122 and Frayne 2007, 194199. An electronic edition of En-metena 1 and all the texts discussed in this paper are available at the website of the Electronic Text Corpus of Sumerian Royal Inscriptions project (http://oracc.museum.upenn.edu/etcsri). The royal inscriptions are quoted with reference to their number in RIME 1 (= Frayne 2007).

2 We thank to Mr. Hashim Hama Abdullah, director of the Sulaymaniyah Museum, for his kind permission to publish T.3860. We are grateful to Mr. Hemn Nuri, Mr. Adel, and Ms. Hazha for their help in obtaining photos of it. A photo of the object was published earlier in Al-Asadi 2015, 108; we are grateful for this reference to Farouk Al-Rawi and Khalid Salim Ismael. 
P513465). ${ }^{3}$ The provenience of the first three is unknown as they were acquired from dealers but are likely to come from the area of Girsu. ${ }^{4}$ VAT 16438 is from Uruk.

IM 191931 is a foundation brick found in Umm Al-Aqarib in 2002. ${ }^{5}$ It is a flat brick, written only on its obverse. ${ }^{6}$ Its preserved five columns contain the text from the beginning, the last preserved line corresponds to 1. 2:11 on the Louvre cone. As each of its columns contained originally approx. 10 lines, it is unlikely that IM 191931 contained the whole text as it is known from the Louvre and the Yale manuscripts, since that would require 20-22 columns.

\section{The relationship of the new manuscript with the Louvre and the Yale mss.}

The inscription on the Sulaymaniyah manuscript is arranged into four columns. Table 1 below shows the correspondence between the first lines of its columns and the lines of the Louvre cone and the Yale jar:?

\begin{tabular}{|l|l|l|l|}
\hline & T.3860 & AO 3004 & NBC 2501 \\
\hline & $1: 1(12$ II.) & $1: 1$ & $1: 1$ \\
\hline & $2: 1(18$ II.) & $1: 26(25$ I..) & $1: 26(25$ II.) \\
\hline & $3: 1(19$ I.) & $2: 35(50$ I.) & $3: 19(56$ I..) \\
\hline & $4: 1(15$ I..) & $6: 2(113$ II.) & $6: 14(111$ II.) \\
\hline last line & $4: 8^{\prime}$ & $6: 29(27$ I.) & $6: 40(28$ I..) \\
\hline
\end{tabular}

TABLE 1

Approximately half of the original object that carries the new manuscript is preserved. So, one may assume that approximately half of the lines are preserved in each column. Due to the shape of T.3860 col. 1 has the least lines. Col. 2 and 3 are longer and contain approximately the same number of lines. Col. 4. has slightly less lines than col. 2. and 3.

It is unlikely that any lines were skipped from the introductory part of En-metena 1 in the new manuscript, one may therefore safely assume that its first column contained 25 lines. The same can be assumed about the last part of the composition: the end of En-metena's blessing (see the commentary to 3:11'-4:7 below) and the final curse probably remained intact. Consequently, the last column of the new manuscript must have contained around 28 lines, which more or less corresponds to the number at which we arrive if we double the number of lines preserved in col. 4 .

The number of the preserved lines in the second and the third column are 18 and 19 respectively. The ms. contains a blank strip separating the beginning and the end of the columns; one may therefore estimate that they both contained around 38 lines originally.

3 AO 3004 will be referred to as the Louvre cone and NBC 2501 as the Yale jar throughout this paper.

4 See Cooper 1986, 56, note 1 and Marzahn 1997, 93.

5 Almamori 2014, 11.

6 Information kindly provided by Almamori (email 15/12/2018).

7 The numbers in brackets in the column of the new manuscript show the number of the preserved lines in each column. The numbers in brackets in the columns of the Louvre and the Yale manuscripts show the number of lines on these manuscripts between the lines that correspond to the first lines of the columns on the new manuscript. In the last row of the tablet, the numbers in brackets show the number of lines on the Louvre and the Yale manuscripts between the lines that correspond to the first and the last line of the 4 th column of the new manuscript. 


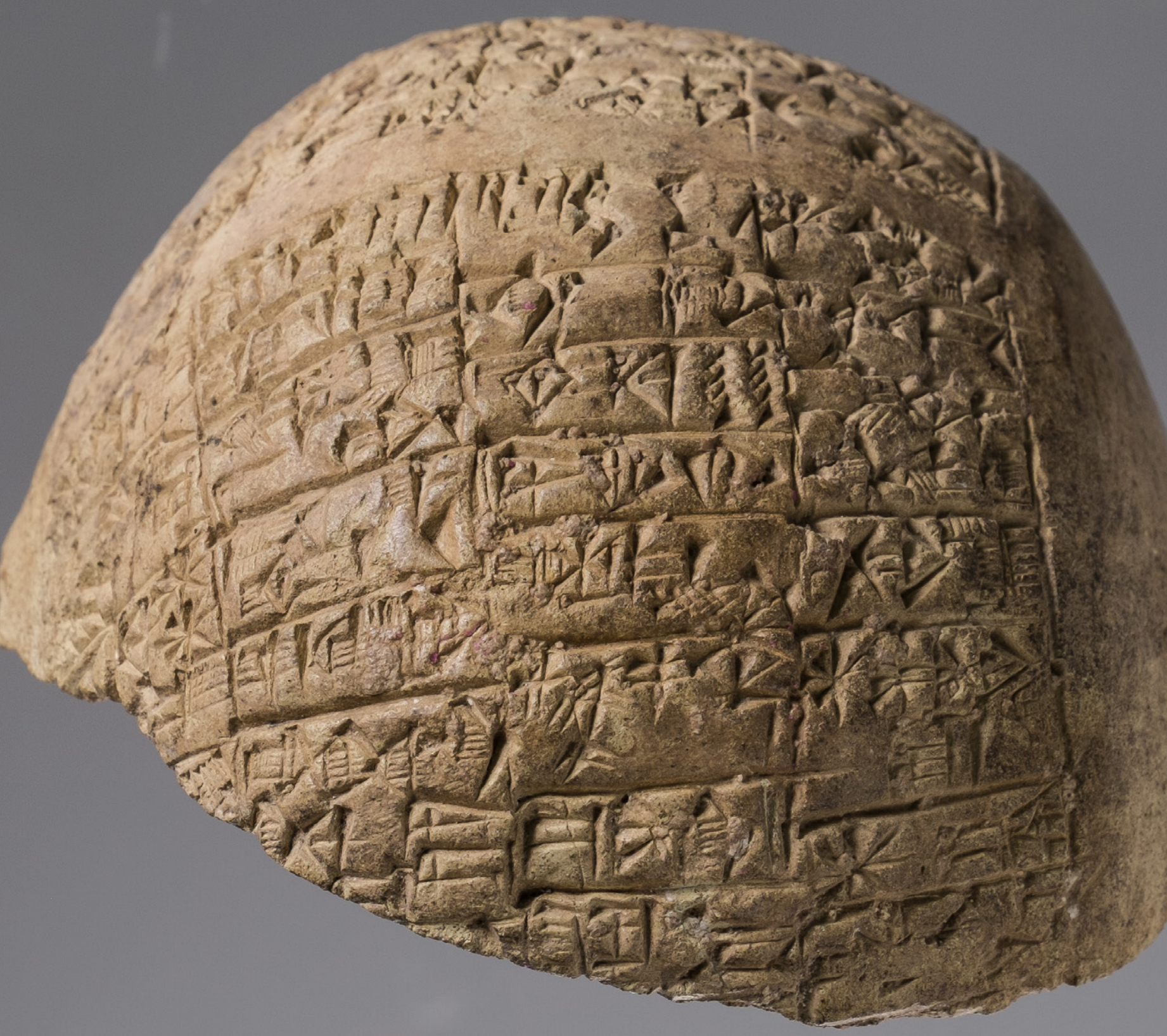

FIGURE 1. The beginning of cols. 2-4. Photo courtesy of the Sulaymaniyah Museum.

The gap in col. 2 of the new manuscript, the gap between 2:6 and 2:1', must have contained approx. 19 lines; while the gap in col. 3, the gap between 3:8 and 3:1' must have contained approx. 20 lines. Table 2 below shows how many lines in the Louvre cone and the Yale jar correspond to the gaps in column 2 and 3 of T.3860. The 5th column of Table 2 shows the number of omitted lines in the new manuscript calculated on the basis of these correspondences.

\begin{tabular}{|l|l|l|l|l|}
\hline & gap in T.3860 & A0 3004 & NBC 2501 & omitted lines in T.3860 \\
\hline col. 2 & approx. 19 II. & $1: 32-2: 21=32$ II. & $2: 1-3: 5=38$ II. & approx. 12-18 II. \\
\hline col. 3 & approx. 20 II. & $3: 38-5: 8,5: 12=46$ I. & $4: 28-5: 31,5: 35=46$ II. & approx. 26 II. \\
\hline
\end{tabular}




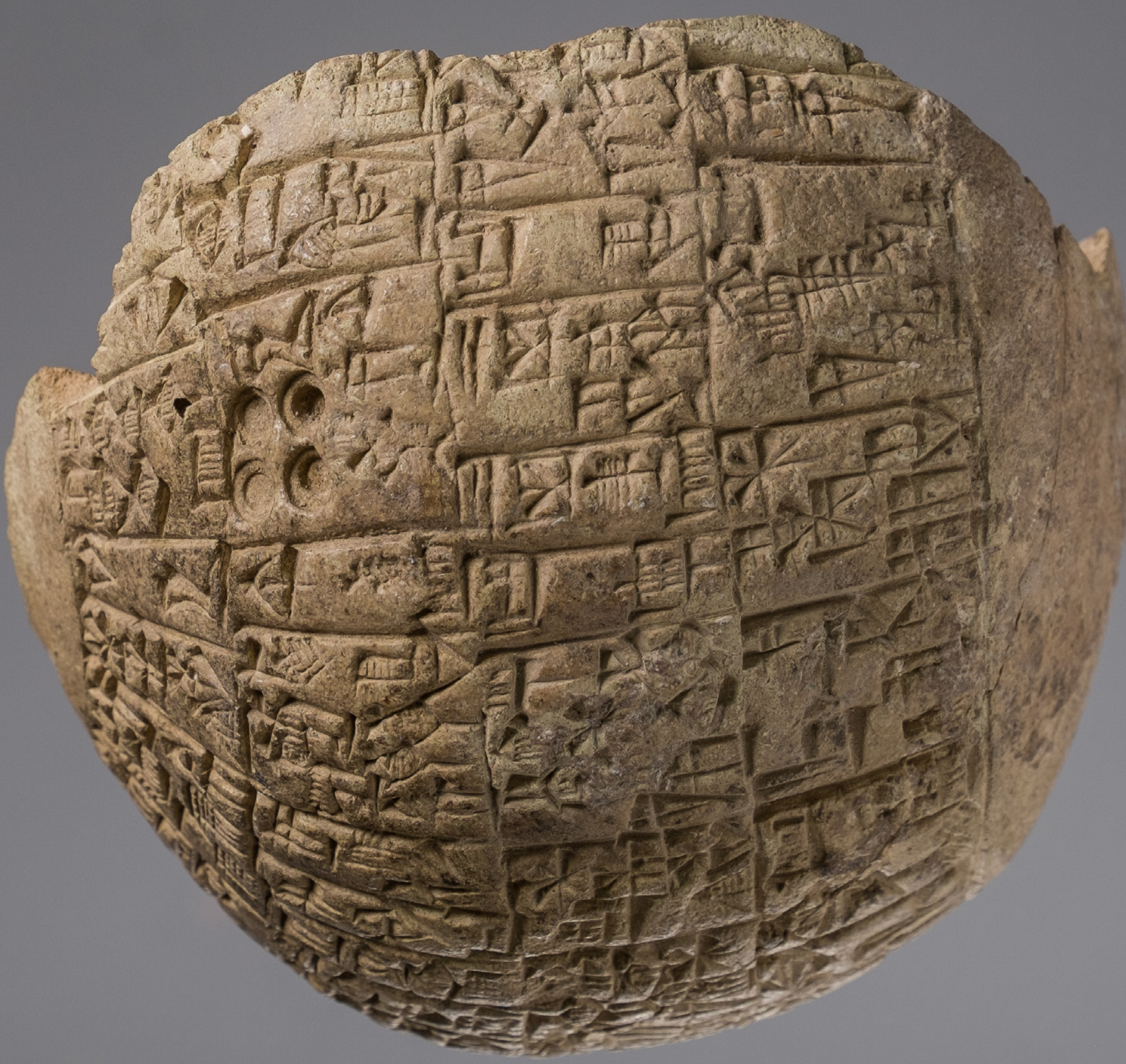

FIGURE 2. The beginning of the text of cols. 2-4 after the gap. Photo courtesy of the Sulaymaniyah Museum.

As regards col. 3, on the basis of the preserved text, we can know certainly that the Sulaymaniyah manuscript skips additional $37+12$ or $13^{8}$ lines in comparison with the Louvre cone and the Yale jar, as it omits 1l. 2:39-3:33, 5:20-6:1 in the Louvre, and 1l. 3:23-4:23, 6:1-13 in the Yale manuscript. In col. 3 of the new manuscript the scribe therefore omitted altogether approximately 76-77 lines as compared to the text of the Louvre and Yale manuscripts.

In sum, the Sulaymaniyah manuscript originally was at least 89 lines shorter than the Louvre and the Yale manuscripts, which have 209 and 220 lines respectively. ${ }^{9}$

The changes in the Sulaymaniyah manuscript may seem unique, but the other manuscripts are not uniform either. The text En-metena 1 is in fact a modern construct created by the modern editions which may conceal the differences in the mss. The passage below is translated by J. Cooper like this:

8 L. 5:30 of the Louvre ms. is written in two lines, 6:11-12 on the Yale ms.

9 The other three manuscripts are too fragmentary to estimate the number of their lines. 
"He extended the (boundary-) channel from the Nun-canal to the Gu'edena, leaving (a) 215 nindan (1290 m.) (strip) of Ningirsu's land under Umma's control and establishing a no man's land there." ${ }^{10}$

\begin{tabular}{|c|c|c|c|}
\hline & AO 3004 & NBC 2501 & \\
\hline $2: 1$ & eg $_{2}-$ be $_{2} \mathrm{id}_{2}$-nun-ta & $\mathrm{eg}_{2}-\mathrm{be}_{2} \mathrm{id}_{2}$-nun-ta & $2: 12$ \\
\hline $2: 2$ & gu $_{2}$-edin-na-še ${ }_{3}$ & gu $_{2}$-edin-na-še ${ }_{3}$ & $2: 13$ \\
\hline \multirow[t]{7}{*}{$2: 3$} & $\mathrm{ib}_{2}$-ta-ni-e $\mathrm{e}_{3}$ & $\mathrm{ib}_{2}$-ta-ni-e $\mathrm{e}_{3}$ & $2: 14$ \\
\hline & & ašag d nin-nir ${ }_{2}$-su-ka & $2: 15$ \\
\hline & & $\begin{array}{l}3 \times 60+3 \times 10+1 / 2 \\
\text { eše }_{2}{ }^{\text {ninda }} \text { ninda }_{x}(D U)\end{array}$ & $2: 16$ \\
\hline & & $\mathrm{a}_{2} \mathrm{umma}^{\mathrm{ki}-\check{s}_{3}}$ & $2: 17$ \\
\hline & & mu-taka & $2: 18$ \\
\hline & & ašag lugal nu-tuku & $2: 19$ \\
\hline & & $\operatorname{ni}^{-k r_{x}}(\mathrm{DU})^{11}$ & $2: 20$ \\
\hline $2: 4$ & $\mathrm{eg}_{2}$-ba na-ru ${ }_{2}-\mathrm{a}$ & $\mathrm{eg}_{2}$-ba na-ru $\mathrm{u}_{2}-\mathrm{a}$ & $2: 21$ \\
\hline $2: 5$ & e-me-sar-sar & e-me-sar-sar & $2: 22$ \\
\hline
\end{tabular}

Actually, we have two different versions of this passage; NBC 2501 adds a 6 lines long section providing supplementary information about the border between Lagaš and Umma (the underlined part of the translation exists only in either of the mss.):

Louvre cone: "He extended its (= the demarcated border's) dyke from the Id-nun canal to the Gu-edena. He set up inscribed stelae everywhere along the dyke.”

Yale jar: "He extended its (= the demarcated border's) dyke from the Id-nun canal to the Gu-edena. He set aside a 215 nindan (wide strip of) Ninnirsu's land along the border of Umma and turned it into a no-man's land. He set up inscribed stelae everywhere along the dyke.”

10 Cooper 1986, 55. Note that Cooper's translation contains a contradiction: if the strip of land had been left under Umma's control, then it could not have functioned as "no man's land". His translation of $\mathbf{a}_{2}$ umma-še ${ }_{3} \mathbf{m u}_{\text {-taka }}$ is also questionable grammatically. With verbs whose meaning involves neither physical nor metaphoric movement, the terminative may express not destination, but location next to, along something (cf. Balke 2006, 207-208 and Zólyomi 2017, 198, exx. [375]-[377]). A “no man's land” should function as a buffer zone excluding the possibility of a sudden and unnoticeable entrance into one's territory. If it lies on the enemy's side, it cannot fulfill this function. A translation like "He set aside a 215 nindan (wide strip of) Ninnirsu's land along the border of Umma” may reflect better the actual situation.

Cooper's translation may also follow from his understanding of $\mathbf{e g}_{2}$ as a levee with a canal on its top. If it is used as a canal it would not make sense to set aside a buffer zone on Lagašs side of the border. Understanding $\mathbf{~ e g}_{2}$ as a bund would support the translation suggested by this paper; cf. the pertinent remarks of Pemberton et al. (1988, 216): “The redefinition of eg would have a major effect on some of the discussions of the topography of the south, especially Lagash .... In particular note that the subject of the long-running dispute between Lagash and Umma would not have been a canal, but a boundary bund. It has always seemed difficult to me that it should have been a water-course, which would not only have required co-operative maintenance but also have constituted a permanent subject of contention, since neither side could control the other's access to and consumption of water.”

11 On the form of an initial locative1 prefix in transitive preterite verbal forms, see Jagersma 2010, 470-473 and Zólyomi 2017, 204-205; note that Jagersma’s description uses a different terminology. 
Here one may say that either the text of the Louvre cone presents an abbreviated version, or the text of the Yale jar presents an extended version of En-metena 1. But the variations in the passage below indicate the neither account may be true.

\begin{tabular}{|c|c|c|c|}
\hline & AO 3004 & NBC 2501 & \\
\hline 3:38 & eg $_{2}$ ki-sur-ra & $\mathrm{eg}_{2}$ ki-sur-ra & $3: 28$ \\
\hline $4: 1$ & ${ }^{\mathrm{d}}$ nin-nir ${ }_{2}$-su-ka & ${ }^{\mathrm{d}}$ nin-nir ${ }_{2}$-su-ka & $3: 29$ \\
\hline $4: 2$ & $\mathrm{eg}_{2}$ ki-sur-ra & $\mathrm{eg}_{2}$ ki-sur-ra & $3: 30$ \\
\hline $4: 3$ & ${ }^{\mathrm{d}}$ nanše & ${ }^{\mathrm{d}}$ nanše & $3: 31$ \\
\hline $4: 4$ & im-dub-ba & im-dub-ba & $3: 32$ \\
\hline $4: 5$ & ${ }^{d}$ nin-nir ${ }_{2}$-su-ka & ${ }^{\mathrm{d}}$ nin-nir ${ }_{2}$-su-ka & $3: 33$ \\
\hline $4: 6$ & $\mathrm{gu}_{2}{ }^{\text {id2idigna-še }}{ }_{3} \mathrm{yal}_{2}$-la & & \\
\hline $4: 7$ & $\mathrm{gu}_{2}-\mathrm{gu}_{2} \operatorname{\eta ir}_{2}-\mathrm{su}^{\mathrm{ki}}-\mathrm{ka}$ & & \\
\hline \multirow[t]{3}{*}{$4: 8$} & nam-nun-da-ki-nar-ra & nam-nun-da-ki-nar-ra & $3: 34$ \\
\hline & & ${ }^{d}$ en-lil ${ }_{x}\left(E_{2}\right)-l a_{2}$ & $3: 35$ \\
\hline & & den-ki-ka & $3: 36$ \\
\hline $4: 9$ & dnin-ḩur-say-ka & dnin-ḩur-san-ka & $3: 37$ \\
\hline $4: 10$ & a-e $i_{3}-m i-e_{3}$ & a-e $i_{3}-m i-e_{3}$ & $3: 38$ \\
\hline
\end{tabular}

Louvre cone: "He washed away the boundary dyke of Ninnirsu, ${ }^{12}$ the boundary dyke of Nanše, (which form) the boundary of Ninnirsu along the bank of the Tigris on the territory of Nirsu, the Namnunda-kinara of Ninhursana.

Yale jar: "He washed away the boundary dyke of Ninnirsu, the boundary dyke of Nanše, the Namnunda-kinara of Enlil, Enki, and Ninhursaya."

Here the Louvre cone specifies the location of Ninnirsu's boundary in 4:6-7; while the Yale jar names two additional deities in $3: 35-36 ;{ }^{13}$ and it is impossible to decide which version represents the "original" one.

The variations in the passages discussed above and those of the Sulaymaniyah ms. (see below) indicate that Early Dynastic royal inscriptions as texts were much less standardized than our modern editions may imply. Manuscripts assigned by us to a single text may vary considerably, reflecting the creativity of the composers who may have adapted them to suit the audience, the occasion, the context, or the carrier. ${ }^{14}$

12 For this translation of the obscure $\mathbf{a}-\mathbf{e} \mathbf{i}_{3}$-mi-e $\mathbf{e}_{3}$, see Zólyomi 2019a. This translation gives further support to the assumption that $\mathbf{e g}_{2}$ in question was in fact not a canal but a boundary bund; see also footnote 10 above.

13 Selz $(1995,119)$ translates NBC 2501 3:34-37 as "Mit Fürstlichkeit gegründet von? Enlil, von? Enki (und) von? Ninhursag(a)". If he is right to assume that the divine names are part of the proper name, then the Louvre version would represent a truncated form of the full name. Alternatively, one may assume that the Namnunda-kinara had different parts identified by the pedestals erected on it (as described in 2:1118 of the Louvre and 2:28-3:2 of the Yale manuscript). Then the composer of the Yale version may have given a more detailed description about the destruction.

14 These examples of variations demonstrate that composers of the Early Dynastic royal inscriptions used the same techniques to manipulate the texts according to their function and use as the scribes who wrote the Assyrian royal inscriptions of the 1st millennium; see Cancik-Kirschbaum 2007. 


\section{Transliteration and translation}

\section{column 1}
1. den-lil ${ }_{\mathrm{x}}\left(\mathrm{E}_{2}\right)$
2. lugal kur-kur-ra
3. rab-ba dinir-dinir-[re $\left.{ }_{2}\right]-$-ne'-ke $_{4}$
4. [inim] rgi-[na-ne ${ }_{2}$-ta]

\section{a gap of 13 lines}

$$
\begin{aligned}
& \text { 1. } \quad\left[\text { na-ru }_{2}\right. \text {-a]-be }
\end{aligned}
$$

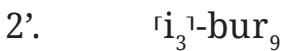

$$
\begin{aligned}
& \text { 3. } \quad \text { redin' lagaški }- \text { še }_{3} \\
& \text { 4. } \quad \mathrm{i}_{3}-\operatorname{kur}_{\mathrm{x}}(\mathrm{DU}) \\
& \text { 5'. dnin-nir }{ }_{2} \text {-su } \\
& \text { 6'. ur-san den-lil }{ }_{\mathrm{x}}\left(\mathrm{E}_{2}\right)-\mathrm{la}_{2}-\mathrm{ke}_{4} \\
& \text { 7'. inim si sa } \text { sene }_{2} \text {-ta } \\
& \text { 8'. ummaki-da }
\end{aligned}
$$

\section{column 2}

$$
\begin{aligned}
& \text { 1. dam-ḩa-ra } \\
& \text { 2. e-da-ak } \\
& \text { 3. inim }{ }^{\mathrm{d} e n-l i l_{\mathrm{x}}}\left(\mathrm{E}_{2}\right)-\mathrm{la}_{2} \text {-ta } \\
& \text { 4. } \quad \text { sa-šuš-gal bi }{ }_{2} \text {-šuš }
\end{aligned}
$$

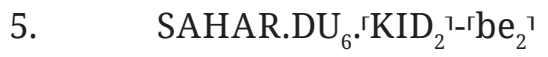

$$
\begin{aligned}
& \text { 6. edin-na ki ba-ni-гus }{ }_{2}{ }^{1-u s_{2}}
\end{aligned}
$$

\section{a gap of approximately 19 lines}

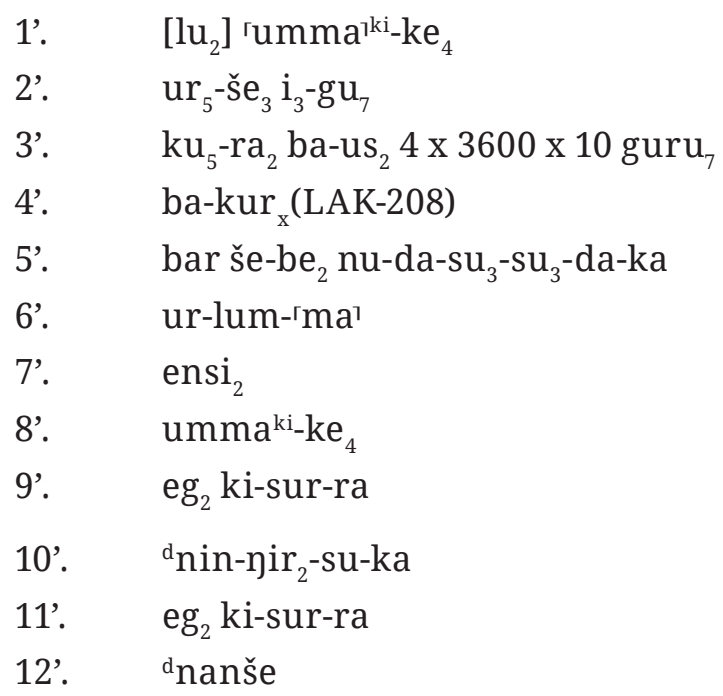

${ }^{1: 1-4}$ By his firm command, Enlil, the king of all lands, the father of all gods, ........

1:1'-4'.... having torn the stele out he (= Nita) entered towards the plain of Lagaš.

1:5'-2:6y (Enlil's) just command, Ninnirsu, Enlil's warrior, did battle with Umma. By Enlil's command, he cast on it the great battle-net, and heaped up burial mounds for it on the plain.
2:1'-4'The leader of Umma took ...... as interest bearing loan. It yielded interest and accumulated to 144,000 guru.

2:5'-3:4 As this (amount) of barley could not be repaid, Ur-Luma, ruler of Umma, destroyed Ninnirsu's boundary levee and Nanše's boundary levee with water. He set fire to their stelae and tore each of them out. 


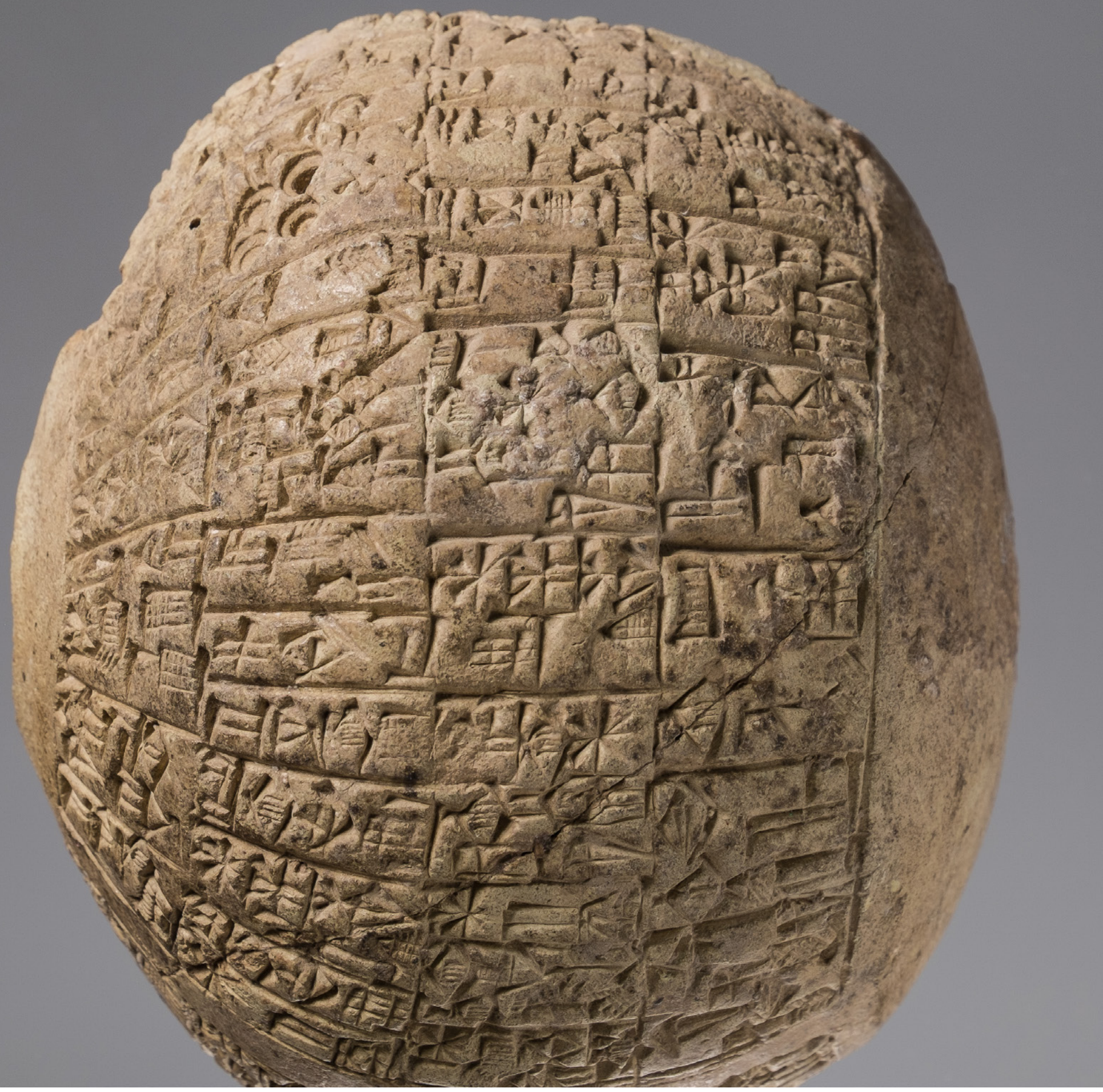

FIGURE 3. The middle part of cols. 2-4. Photo courtesy of the Sulaymaniyah Museum. 


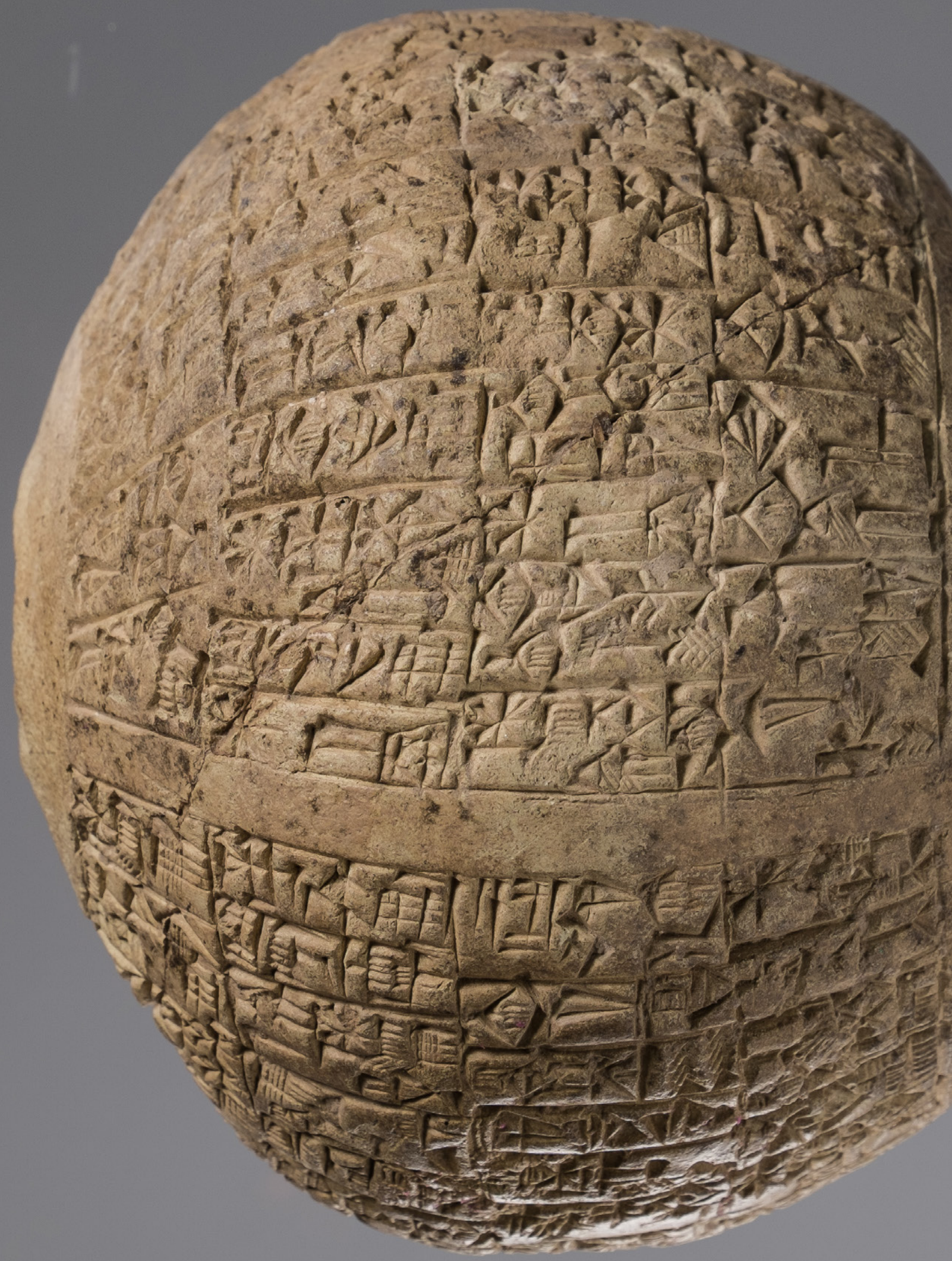

FIGURE 4. The beginning and end of cols. 2-4. Photo courtesy of the Sulaymaniyah Museum. 


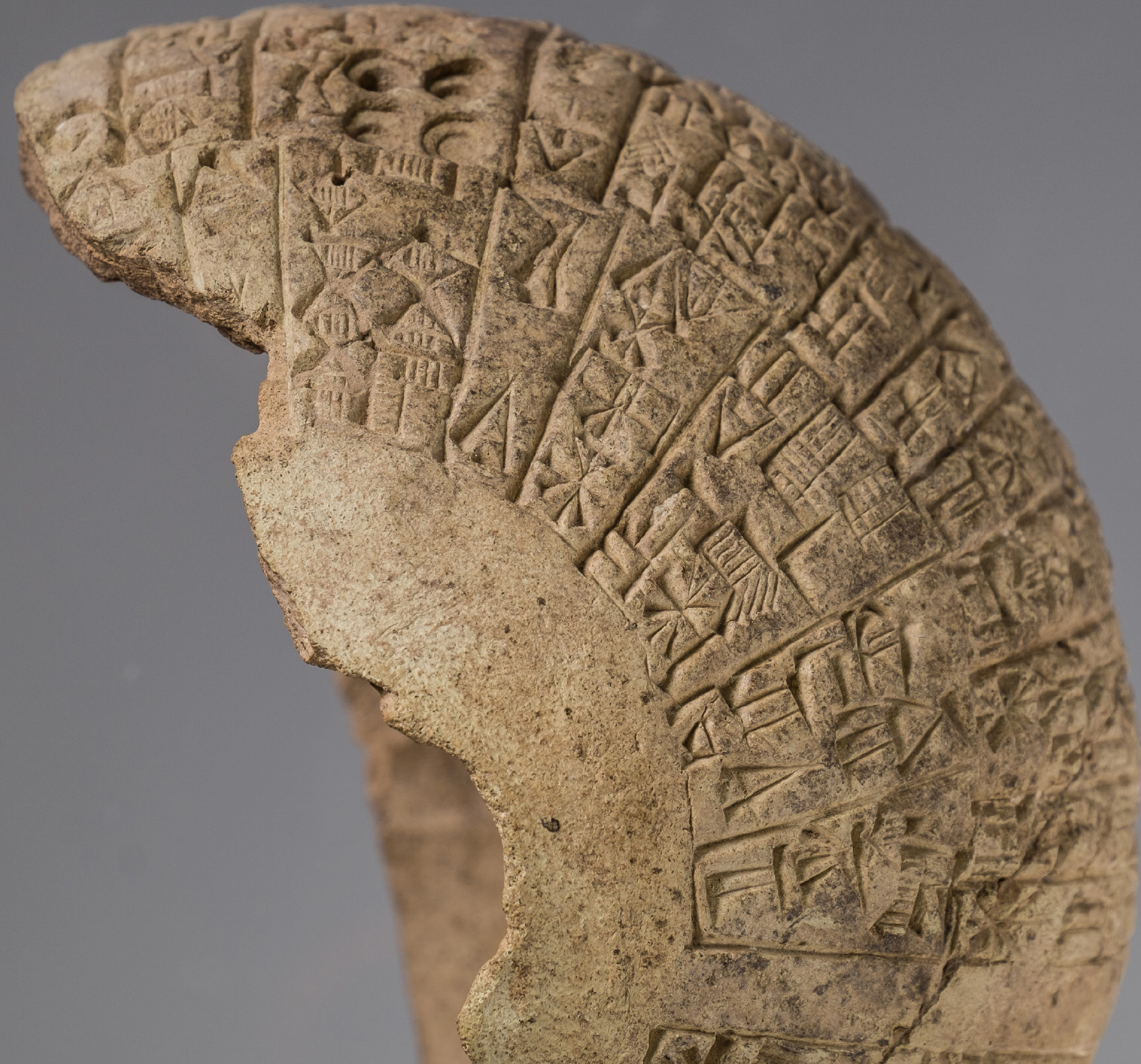

FIGURE 5. Part of the upper part of T.3860 with the end of col. 1. Photo courtesy of the Sulaymaniyah Museum. 


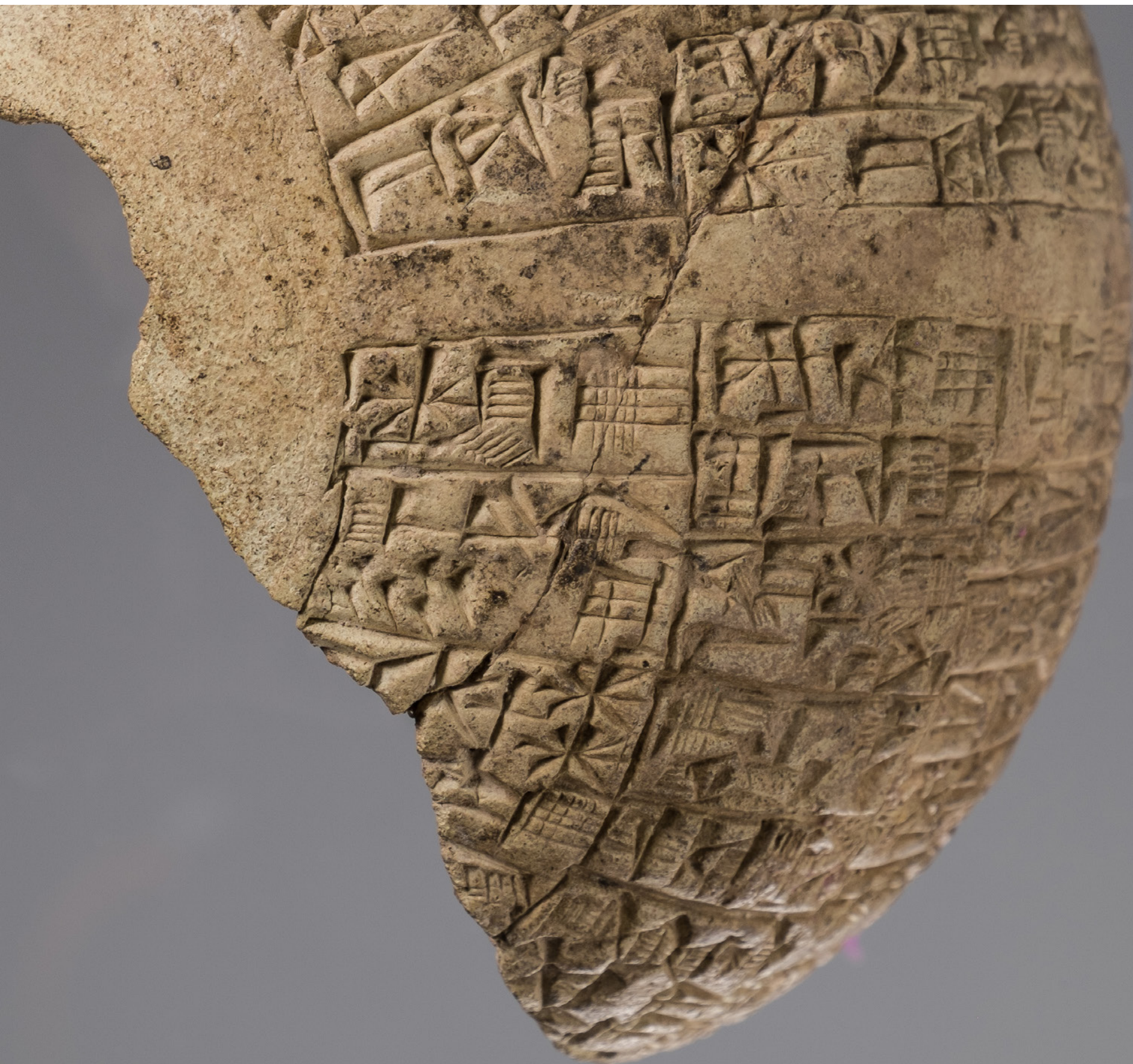

FIGURE 6 (ABOVE). Part of the upper part of T.3860 with the beginning of col. 1. Photo courtesy of the Sulaymaniyah Museum.

FIGURE 7 (NEXT PAGES, LEFT). Bottom of T.3860. Photo courtesy of the Sulaymaniyah Museum.

FIGURE 8 (NEXT PAGES, RIGHT). Inside of T.3860. Photo courtesy of the Sulaymaniyah Museum. 


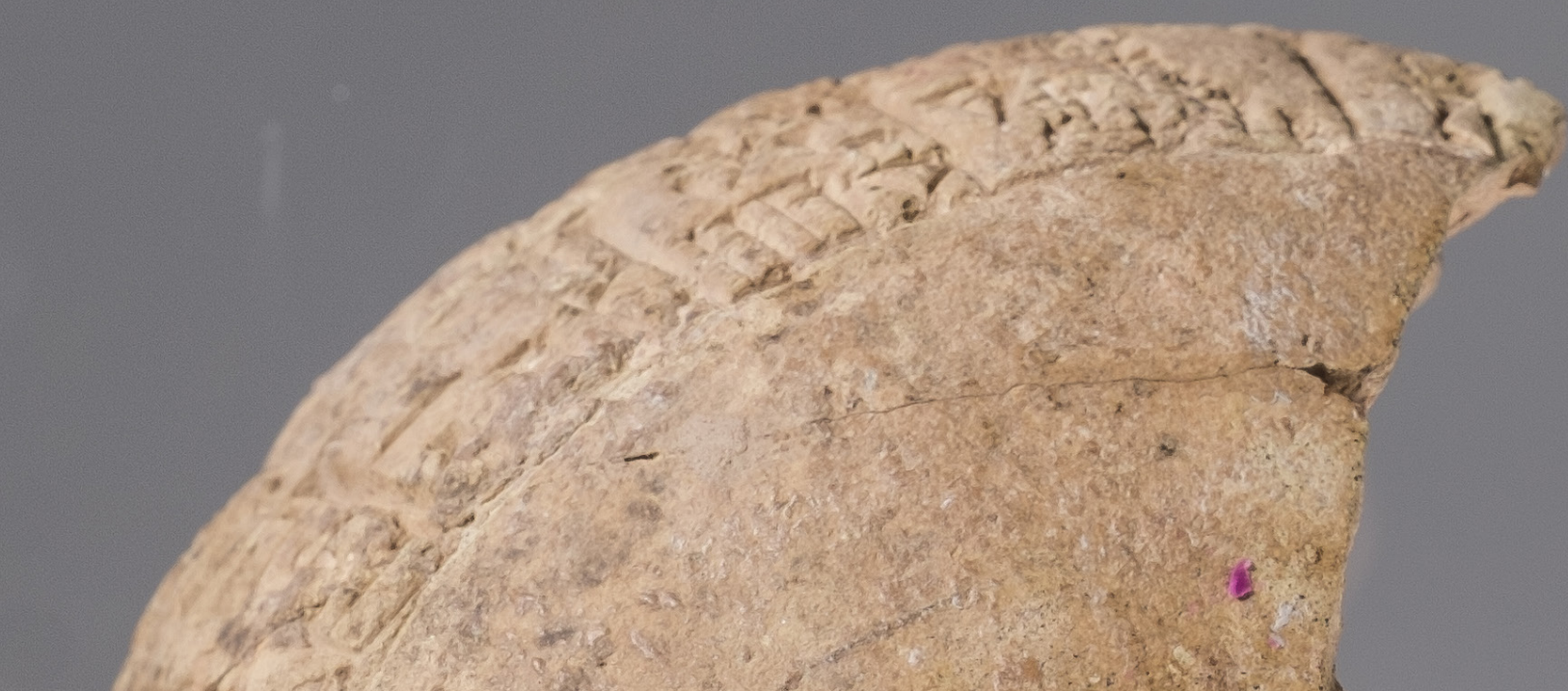




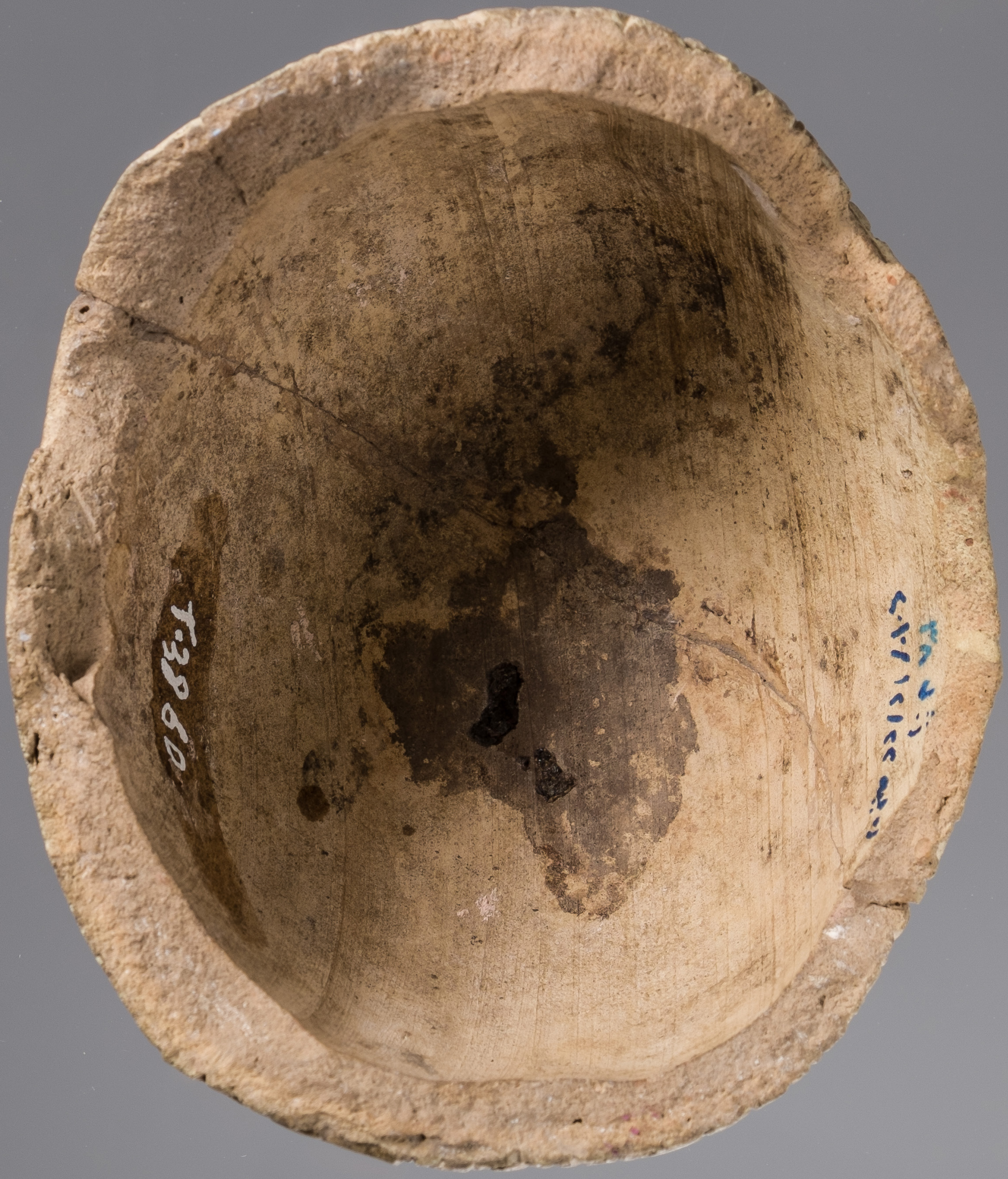




\section{column 3}
1. a-e $\mathrm{i}_{3}-\mathrm{mi}^{-\mathrm{e}_{3}}$
2. $\quad$ na-ru $\mathrm{r}_{2}-\mathrm{a}-\mathrm{be} \mathrm{e}_{2}$
3. izi ba-šum
4. $\quad \mathrm{i}_{3}$-bur $_{9}-$-bur $_{9}$
5. $\quad \mathrm{il}_{2}-\mathrm{le}$
6. nam-ensi ${ }_{2}$
7. ummaki-a
8. šu e-ma-rtir

\section{a gap of approximately 20 lines}

0' [nam-nun-da-ki-nar-ra]

1'. $\quad \operatorname{rur}_{2}{ }^{1}$-be ${ }_{2}$ na $_{4}$ mu-ni-du

2'. $\quad$ eg $_{2}-\mathrm{be}_{2}$

3'. id2idigna-ta

4'. $\quad$ id $_{2}$-nun-še ${ }_{3}$

5'. e-ak

6. lugal ki an-na-гап ${ }_{2}-$-na $_{2}{ }^{1}-$ ne $_{2}$

7. $\quad{ }^{\mathrm{d}}$ nin-nir ${ }_{2}$-su-ra

8. nin ki an-na-an ${ }_{2}-$-na $_{2}-$-ne $_{2}$

9'. dnanše

10'. ki-be ${ }_{2}$ mu-na-gi

11'. dinir en-mete-na-ka

\section{column 4}

$\begin{array}{ll}\text { 1. } & \text { dšul-MUŠxPA } \\ \text { 2. } & \text { nam-til } \\ \text { 3. } & \text { en-mete-na-ka-še } \\ \text { 4. } & \text { ud ul-la-še } \\ \text { 5. } & { }^{\mathrm{d}} \text { nin-nir } \\ 2 & \text {-su-ra } \\ \text { 6. } & { }^{\mathrm{d}} \text { nanše } \\ \text { 7. } & \text { 'he }_{2} \text {-na'-ši-rgub }\end{array}$

a gap of 13 lines

\begin{tabular}{|c|c|}
\hline 1’. & {$\left[\mathrm{sa} \mathrm{šu}_{4}\right.$ gal]-「ne ${ }_{2}^{\top}$} \\
\hline 2'. & $\mathrm{u}_{3}-\mathrm{ni}$-šu $\mathrm{u}_{4}$ \\
\hline 3'. & šu mah giri ${ }_{3}$ mah-ne $_{2}$ \\
\hline 4'. & an-ta he $e_{2}-\eta a_{2}-\eta a_{2}$ \\
\hline 5'. & nam-lu ${ }_{2}-l u_{7}$ iri-na \\
\hline 6'. & šu $u_{3}$-na-zig \\
\hline 7’. & 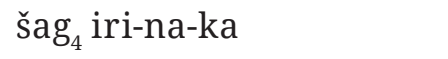 \\
\hline $8^{\prime}$. & ha-ne ${ }_{2}-$ gaz-ze $_{\mathrm{x}}\left(\mathrm{AB}_{2} \cdot \mathrm{S̆}_{3} \cdot \mathrm{GI}\right)$ \\
\hline
\end{tabular}

3:5-8Il claimed the rulership of Umma for himself.

3:0'-10'He built the substructure of [the Namnunda-kinara] of stone. He constructed its dyke from the Tigris to the Id-nun. For Ninnirsu, his master who loves him, and for Nanše, the lady who loves him, he restored it.

3:11'-4:7May En-metena’s personal god,

Šul-MUŠxPA, intercede forever for En-metena's well-being with Ninnirsu and Nanše!

4:1'-4'Having cast on him his great battle-net, may [Ninnirsu] pound him down with his majestic hands, tread on him with his majestic feet!

4:5'-8'Having revolted against him in his city, may the people kill him in the middle of his city! 


\section{Commentary}

1:2': Frayne states that "[a]nother possibility is to read the verb as padr = kasāpu(m) "to break into bits." ${ }^{\prime 15}$ Note that this reading is implausible because of the prefix-chain of the verbal form (cf. also l. 3:4). A reading like pad would require e-pad because of the Old Sumerian vowel harmony. ${ }^{16}$

2:3': This line is written in two lines in the Louvre cone (2:24-25) and the Yale jar (3:8-9). In the Sulaymaniyah manuscript the GAL sign is missing, which renders the number here 60 times less: 144,000; compared to 8,640,000 in the Louvre cone and the Yale jar.

3:4 and 5: Between these two lines, the Louvre cone (2:39-3:33) and the Yale jar (3:23-4:23) contain 37 additional lines, which are not included in the Sulaymaniyah version of En-metena 1:

"He destroyed the pedestals erected for the gods that were set up at Namnunda-kinara. He hired foreigners and crossed Ninnirsu's boundary levee. In the Ugiga field, the field of Ninnirsu, Enana-tum, ruler of Lagaš, fought with him. En-metena, the beloved child of En-ana-tum, defeated him. Ur-Luma escaped, (En-metena) forced him back to Umma. 60 teams of his donkeys were abandoned on the bank of the Luma-nirnunta canal. The bones of their personnel were left strewn all around the plain. He piled up their burial mounds in five places. Then Il, who was the temple administrator of Zabalam, marched from Nirsu until Umma in retreat."

This long omission suggests that the Sulaymaniyah ms. may definitely be considered an abbreviated version, since without the information contained in these 37 lines the clause about Il in the Sulaymaniyah version (3:5-8) makes little sense.

3:1': The Louvre cone (5:13) and the Yale jar (5:35) write this line as $\mathbf{u r}_{2}$-be $\mathbf{b}_{2} \mathbf{n} \mathbf{a}_{4}$-a mu-na-ni-du . The missing line before 3:1', referred to as 3:0' above, may almost certainly be restored as namnun-da-ki-nar-ra.

On the Louvre cone and the Yale jar, the lines corresponding to 3:2'-5' precede the lines corresponding to 3:0'-1'. On these manuscripts the passage sounds like this:

"(En-metena) constructed the dyke from the Tigris to the Id-nun. He built the substructure of the Namnunda-kinara of stone for him. For Ninnirsu, his master who loves him, and for Nanše, the lady who loves him, he restored it."

In this version of the passage the last clause is understood usually to refer to the restoration of the Namnunda-kinara, as the paraphrase of Bauer and the translation of Cooper below show:

"Die Namnundakigara genannte Stätte stellt er wieder her und versieht sie mit einem steinernen Fundament”. ${ }^{17}$

"He built the foundations of the Namnundakigara for him (Ningirsu) out of stone, restoring for the master who loves him, Ningirsu, and for the mistress who loves him, Nanshe."18

If the Sulaymaniyah version is considered a genuine variation and not one due to erroneous copying, then this version may imply that the dyke from the Tigris to the Id-nun and the Namnunda-kinara were the same, i.e. the latter was the name of the former.

\footnotetext{
15 Frayne 2007, 194.

16 Cf. Zólyomi 2017, 29-31.

17 Bauer 1998, 473.

18 Cooper 1986, 55.
} 
As regards the function of Namnunda-kinara's strengthening, see Pemberton et al. mentioning Willcocks who "refers to attempts to reinforce the slopes of the dykes against the action of waves with masonry or by growing grass" 19 in Egypt.

3:2'-3': These two lines are written in one line in the Louvre cone (5:9) and the Yale jar (5:32).

3:11'-4:7: These lines of the Sulaymaniyah manuscript correspond to a twelve lines longer passage in the Louvre cone (5:19-6:8) and the Yale jar (5:42-6:8), as the comparison between the versions below demonstrate: ${ }^{20}$

\section{Sulaymaniyah ms.}

3:11 $\quad$ dinir en-mete-na-ka

\section{En-metena $1^{21}$}

\begin{tabular}{|c|c|}
\hline en-mete-na & $5: 19$ \\
\hline ensi $_{2}$ & $5: 20$ \\
\hline lagaški & $5: 21$ \\
\hline nidru šum ${ }_{2}$-ma & $5: 22$ \\
\hline den-lil ${ }_{x}\left(E_{2}\right)-l_{2}$ & $5: 23$ \\
\hline neštug $_{2}$ šum $_{2}$-ma & $5: 24$ \\
\hline${ }^{\mathrm{d}}$ en-ki-ka & $5: 25$ \\
\hline šag $_{4} \mathrm{pad}_{3}$-da & $5: 26$ \\
\hline dnanše & $5: 27$ \\
\hline ensi $i_{2}$-gal & $5: 28$ \\
\hline dnin-nir ${ }_{2}$-su-ka & $5: 29$ \\
\hline $\mathrm{lu}_{2}$ inim dinir-re $\mathrm{e}_{2}$-ne dab $\mathrm{da}_{5}$-ba & $5: 30$ \\
\hline dinir-ra-ne $_{2}$ & $6: 1$ \\
\hline dšul-MUŠxPA & $6: 2$ \\
\hline nam-til ${ }_{3}$ & $6: 3$ \\
\hline en-mete-na-ka-še ${ }_{3}$ & $6: 4$ \\
\hline ud ul-la-še ${ }_{3}$ & $6: 5$ \\
\hline dnin-nir ${ }_{2}$-su-ra & 6:6 \\
\hline dnanše & $6: 7$ \\
\hline$h_{2} e_{2}$-na-ši-gub & $6: 8$ \\
\hline
\end{tabular}

In the long version of the Louvre cone and the Yale jar, the grammatical subject of the finite verb (he $_{2}$-na-ši-gub), the god Šul-MUŠxPA, is expressed with a complex construction. It is an appositive construction consisting of two parts:

i) a left-dislocated (= anticipatory) genitive construction. The possessum of this genitive construction is the word "(personal) god" (dinir) in 6:1. The left-dislocated possessor is En-metena, whose name in 5:19 is followed by six epithets in 5:20-30;

ii) the name of En-metena's personal god (dšul-MUŠxPA) in 6:2.

19 Pemberton et al. 1988, 215. The reference is to Willcocks 1899, 116-118.

20 On this passage, see Zólyomi 2019b.

21 The composite text is based on AO 3004, NBC 2501, and VAT 16438; it follows the line numbering of the Louvre manuscript. 
The scribe who wrote the Sulaymaniyah manuscript abridged the text i) by omitting parts of the text: he left out all six epithets of En-metena; and ii) by replacing a complex structure by a simpler one: he substituted the left-dislocated genitive construction with a simple, not left-dislocated genitive construction: dinir en-mete-na-ka "En-metena’s personal god".

4:5'-8': Cooper translated these lines as "May the people of his own city, after rising up against him, kill him there within his city!”, ${ }^{22}$ This translation would, however, require nam-lu ${ }_{2}-\mathbf{l u}_{7}$ irina-ke ${ }_{4}$ in 4:5'. The phrase in question may be interpreted to function either as the subject of the compound verb šu - zig "to revolt (lit. to raise the hand)" in 4:6'; or as the subject of the verb gaz "to kill" in 4:8'. ${ }^{23}$ In either case it should be in the ergative. The wordform iri-na may therefore not be the possessor nam-lu $\mathbf{u}_{2}-\mathbf{l} \mathbf{u}_{7}$, only a place adverbial in the locative.

\section{References}

AL-AsADI, Y. 2015: Vultures Obelisk: A Model for Integration Narrative between the Art Work and of the Sumerian Writings. Magazine of Historical Studies and Archaeology 47, 52-122 (in Arabic).

Almamori, H. O. 2014: Gišša (Umm al-Aqarib), Umma (Jokha), and Lagaš in the Early Dynastic III Period. Al-Rāfidān 35, 1-37.

BALKE, T. 2006: Das sumerische Dimensionalkasussystem. (Alter Orient und Altest Testament 331) Münster.

BAUER, J. 1998: Der vorsargonische Abschnitt der mesopotamischen Geschichte. In: BAUER, J. ET AL.: Mesopotamien. Späturuk-Zeit und Frühdynastische Zeit. (Orbis Biblicus et Orientalis 160, I) Fribourg - Göttingen, 431-585.

Cancik-Kirschbaum, E. 2007: Text - Situation - Format. Die materielle Gegenwart des Textes. In: Morenz, L. - Scновсн, S. (eds.): Was ist ein Text? Alttestamentliche, ägyptologische und altorientalische Pespektiven. (Beihefte zur Zeitschrift für die alttestamentliche Wissenschaft 362) Berlin - New York, 155-168.

Cooper, J. S. 1986: Sumerian and Akkadian Royal Inscriptions, Vol. I: Presargonic Inscriptions. (The American Oriental Society. Translations Series 1) New Haven.

Frayne, D. 2007: Presargonic Period (2700-2350 BC). (The Royal Inscriptions of Mesopotamia. Early Periods 1) Toronto. https://doi.org/10.3138/9781442688865

Jagersma, A. H. 2010: A descriptive grammar of Sumerian. PhD Dissertation, Universiteit Leiden.

MARZAHn, J. 1997: Entemena in Uruk. Baghdader Mitteilungen 28, 87-96.

Pemberton, W. - Postgate, J. N. - Smyth, R. F. 1988: Canals and bunds, ancient and modern. Bulletin on Sumerian Agriculture 4, 207-221.

SELZ, G. 1995: Untersuchungen zur Götterwelt des altsumerischen Stadtstaates von Lagaš. (Occasional Publications of the Samuel Noah Kramer Fund 13) Philadelphia.

Steible, H. - Behrens, H. 1982: Die altsumerischen Bau- und Weihinschriften, I-II. (Freiburger Altorientalische Studien 5) Stuttgart.

WiLLcocks, W. 1899, Egyptian Irrigation. 2nd edition. London - New York.

ZóLYomi, G. 2017: An Introduction to the Grammar of Sumerian. With the collaboration of Sz. Jáka-Sövegjártó and M. Hagymássy. Budapest.

ZóLyomi, G. 2019a: On the meaning of a-e $\mathrm{i}_{3}-\mathrm{mi}_{-} \mathrm{e}_{3}$ in En-metena 1. Nouvelles Assyriologiques Brèves et Utilitaires, 2-5 (No. 2)

ZóLYomi, G. 2019b: Native-speaker intuitions about genitive constructions in Sumerian. Altorientalische Forschungen 46, 301-311. https://doi.org/10.1515/aofo-2019-0019

22 Cooper 1986, 56. Frayne's $(2007,199)$ translation differs only in changing "his city” to "his (own) city” in the last clause.

23 Note that Steible and Behrens (1982, I, 245) also consider the phrase a genitive construction: "die Bevölkerung seiner Stadt”. 


\section{HUNGARIAN ASSYRIOLOGICAL HAR REVIEW}

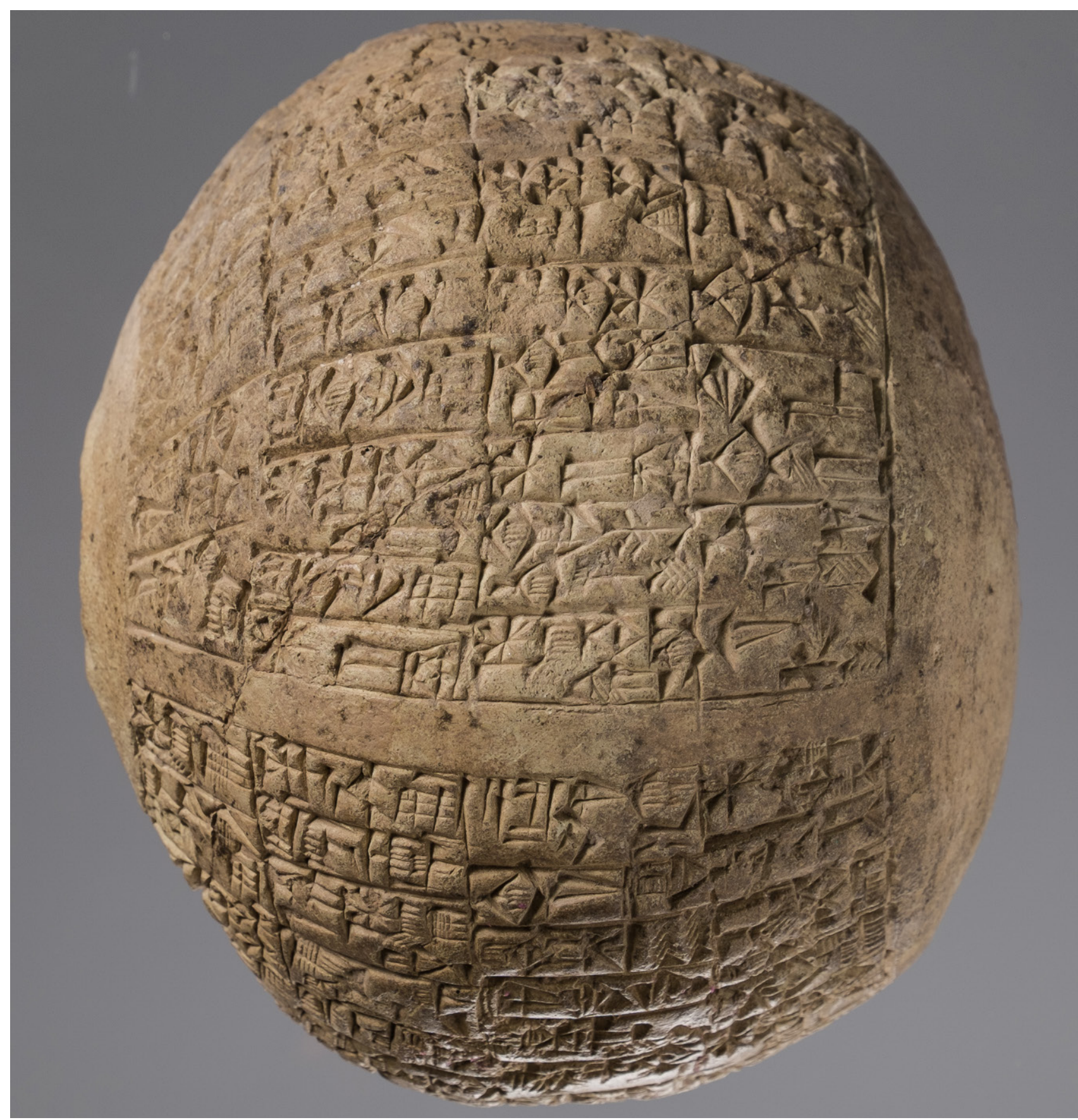

VOLUME 1 | ISSUE 1 | 2020 
ON THE COVER:

Jar-like clay object (T.3860),

Sulaymaniyah Museum. See pp. 21-39.

Photo: Suleymaniah Museum 


\section{HUNGARIAN ASSYRIOLOGICAL REVIEW

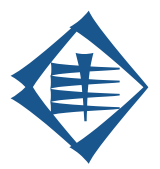 \\ VOLUME 1, ISSUE 1 \\ 2020}

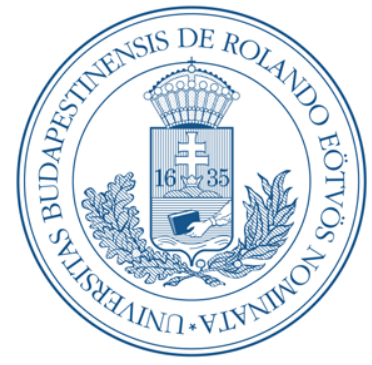

Institute of Archaeological Sciences

Institute of Ancient and Classical Studies

Eötvös Loránd University

Budapest 


\section{HUNGARIAN}

\section{HAR - Hungarian Assyriological Review}

Journal of the Institute of Archaeological Sciences and the Institute of Ancient and Classical Studies (Department of Assyriology and Hebrew Studies), Eötvös Loránd University, Budapest, Hungary.

HAR is a peer-reviewed electronic journal (HU ISSN 2732-2610) published in two issues per year. The journal covers the philology and the archaeology of the Ancient Near East, publishing research articles, brief notes, and field reports.

Papers in HAR are published under the platinum open access model, which means permanent and free access in downloadable format (pdf) for readers and no publication fees for authors. The issues can be both downloaded for free and ordered as printed volumes at own cost.

For article submission guidelines, see https://harjournal.com/author-guidelines/

\section{Editorial board}

Editor-in-chief (szerkesztésért felelös személy):

Gábor Kalla, Eötvös Loránd University, Budapest

\section{Associate editors:}

Zsombor J. Földi, Ludwig-Maximilians-Universität, München

Zsolt Simon, Ludwig-Maximilians-Universität, München

\section{Editorial board:}

Tamás Dezső, Eötvös Loránd University, Budapest

Gábor Zólyomi, Eötvös Loránd University, Budapest

Technical editor:

Attila Király

Publisher (kiadó és kiadásért felelös személy):

Gábor Kalla, Eötvös Loránd University, Budapest

\section{Registered office (a kiadó székhelye):}

Institute of Archaeological Sciences, Múzeum Krt. 4/B., 1088 Budapest, Hungary.

Email address: info@harjournal.com

\section{Design and typesetting:}

Attila Király (attila@litikum.hu)

using Noto font family by Google Inc., under the terms of the SIL Open Font License. 


\section{CONTENTS}

\section{Hungarian Assyriological Review}

\section{volume 1, issue 1, 2020}

Editorial

Zsombor J. Földi, Gábor Kalla, Zsolt Simon

Paratactic relative clauses in Sumerian

Gábor Zólyomi

An abbreviated version of En-metena 1 from the Sulaymaniyah Museum

Ardalan Khwshnaw - Gábor Zólyomi

Cuneiform Luwian =ku(wa): form and meaning

Zsolt Simon

The property of the city, the property of the king? A new fragment of YOS 12, 321

zsombor J. Földi

Intercalary Months and Interest-bearing Loans in Babylonia.

A Promissory Note from the Egibi Archive

Zoltán Csabai

Hungarian Assyriological Review

Author Guidelines 
